\title{
Introduction of Novel Method for Sweetening of Sour Petroleum
}

\author{
Rasoul Najjar ${ }^{1}$, and Farshad Farahbod ${ }^{2}$ (Corresponding Author)
}

\begin{abstract}
The subject of this experimental report is the application of nano particles in petroleum refinement. Sulfur removal from petroleum using mixed bed which contains nano molybdenum oxide and nano cobalt oxide, each of them in 50 volume percentage, is considered in this study. The $\mathrm{X}$ factor is defined as quality index in sulfur removal process. The properties related to the process characterization which is defined as $\mathrm{X}$ factor and pressure drop, are evaluated experimentally. Catalyst diameter, bed diameter, bed height, temperature and pressure, superficial velocity is changed and the effect of these on the value of $\mathrm{X}$ factor is obtained to present the optimum operational and geometrical parameters. Also, the difference between mathematical and experimental data of $\mathrm{X}$ factor is reported as uncertainty. Cost evaluation is also presents due to operation pressure and temperature.
\end{abstract}

Keywords - operating and geometric condition; desulphurization; efficiency.

\section{INTRODUCTION}

$\mathrm{D}$ ESULFURIZATION of crude oil is an important process used in a petroleum refinery to reduce the sulfur concentration and production of fuel products such as gasoline, jet fuel, kerosene, diesel and heating oil [1-3]. So, the resulting fuels meet environmental protection standards [4-7]. The challenge of fulfilling the world's growing transportation energy needs is no longer a simple issue of producing enough liquid hydrocarbon fuels [8]. This challenge is instead accentuated by a complex interplay of environmental and operational issues [9]. Environmental issues include societal demands that liquid hydrocarbon fuels be clean and less polluting [10]. The emergence of new refining processes and the increasing use of new forms of energy production, e.g., fuel cells, exemplify operational issues. Together, these trends are driving the need for deep desulfurization of diesel and jet fuels.

\section{MATERIALS AND METHODS}

\section{A. Review Stage}

All the equipment's which contact with sour oil is made up of stain less steel preventing the corrosion problem. Sour oil feed tank is equipment with an agitator to provide

${ }^{1}$ Department of Chemical Engineering, Sirjan Branch, Islamic Azad University, Sirjan, Iran.

${ }^{2}$ Department of Chemical Engineering, Firoozabad Branch, Islamic Azad University, Firoozabad, Iran. homogenous feed flow and prevent sedimentation. Oil flow rate is adjusted by a valve and flow meter in line of oil movement. After passing the filter the oil flows through a pump to reach the required pressure of feed. The oil flows from the top of vessel to down through the distributor on the catalytic packed bed contains nano carbon tubes. 5 liters of sour petroleum with $30 \mathrm{ppm}$ of sulfide hydrogen concentration is entrance the bed and this liter is extrance with the $0.24 \mathrm{ppm}$ of sulfide hydrogen, finally. The upper than $99.2 \%$ of sulfide hydrogen is removed the optimum operating conditions. The physical properties of Carbon nanotubes are mentioned in the Table 1.

\begin{tabular}{|c|c|c|c|c|c|}
\hline Type & $\begin{array}{c}\text { Young's } \\
\text { modulus } \\
(\mathrm{TPa})\end{array}$ & $\begin{array}{c}\text { Tensile } \\
\text { strength } \\
(\mathrm{GPa})\end{array}$ & $\begin{array}{c}\text { Elongation } \\
\text { at break } \\
(\%)\end{array}$ & Size (nm) & $\begin{array}{c}\text { Specific } \\
\mathrm{area}\left(\mathrm{m}^{2} / \mathrm{gr}\right)\end{array}$ \\
\hline $\begin{array}{c}\text { Powder, } \\
\text { Black }\end{array}$ & 0.94 & 126.2 & 23.1 & $\begin{array}{c}50, \\
\text { averagely }\end{array}$ & \rangle 1000 \\
\hline
\end{tabular}

The application of Carbon nanotubes related to the traditional methods is clear. The usage of Carbon nanotube is cause to promote in the sweetening process. in addition, the cost of usage of energy is very high in the traditional methods, while the consumption energy in this method is very low. The total cost which is equal to the fixed cost and operating cost is very lower than the other methods. So, the introduced method is very cost beneficial. The nano particles is fixed on the flat plate and can remove the sulfur compounds by physical adsorption. The fixed plates are situated in the reactor. These layers role as bed in the reactor. The layers can be changed after each run. The time of each run is 45 minutes, approximately. The 20 gram of Carbon nanotubes are applied in this experiment. The color of Carbon nanotubes is black and its type is powder. The specific area and the other properties of used Carbon nanotubes are stated in the Table 1.

\section{RESUlts AND DisCUSSIONS}

\section{A. Material Balance}

The material balance is according to the general material rule. The input feed is equal to the output product. The equation 1 states the material balance.

\begin{tabular}{|l|l|}
\hline Qin $=Q_{\text {out }}$ & 1 \\
\hline
\end{tabular}

To evaluate the effect of important operation and manufacturing parameters on the performance of the sweetening process, experiments are held. The quality 
performance of the process is reported as the one mines the ratio of outlet sulfur concentration to the inlet sulfur concentration, $\mathrm{X}=1-\mathrm{C} / \mathrm{C} 0$. The amount of $0.6 \mathrm{ppm}$ sulfur in outlet petroleum is desirable according to the standards.

$$
X=1-C / C_{o}
$$

\section{B. Investigation of operating parameters}

Sulfur removal from oil by catalytic bed happens chemically and physically. Appropriate reaction temperature and pressure fasts the process which is selected due to the species and safety parameters. On the other hand, physical mass transfer and the mass transfer coefficient is also related the operation temperature and pressure.

Mass transfer phenomenon from oil phase on solid phase is dependent on the equilibrium conditions. Operation pressure and temperature affects the equilibrium state. Deviation from equilibrium condition results the adsorption mass transfer. So, in this part these majors are considered. Finding the appropriate pressure and temperature is done by measuring the amount of $\mathrm{X}$ factor in low temperature values of 30,35 , 40, 45 and $50 \mathrm{C}$ and suggested pressure values of $1,1.5,1.7$ and 2 atm. legally, the higher pressure and lower temperature helps adsorption from oil to solid surface. Figure 1 shows the results of finding the appropriate operation conditions.

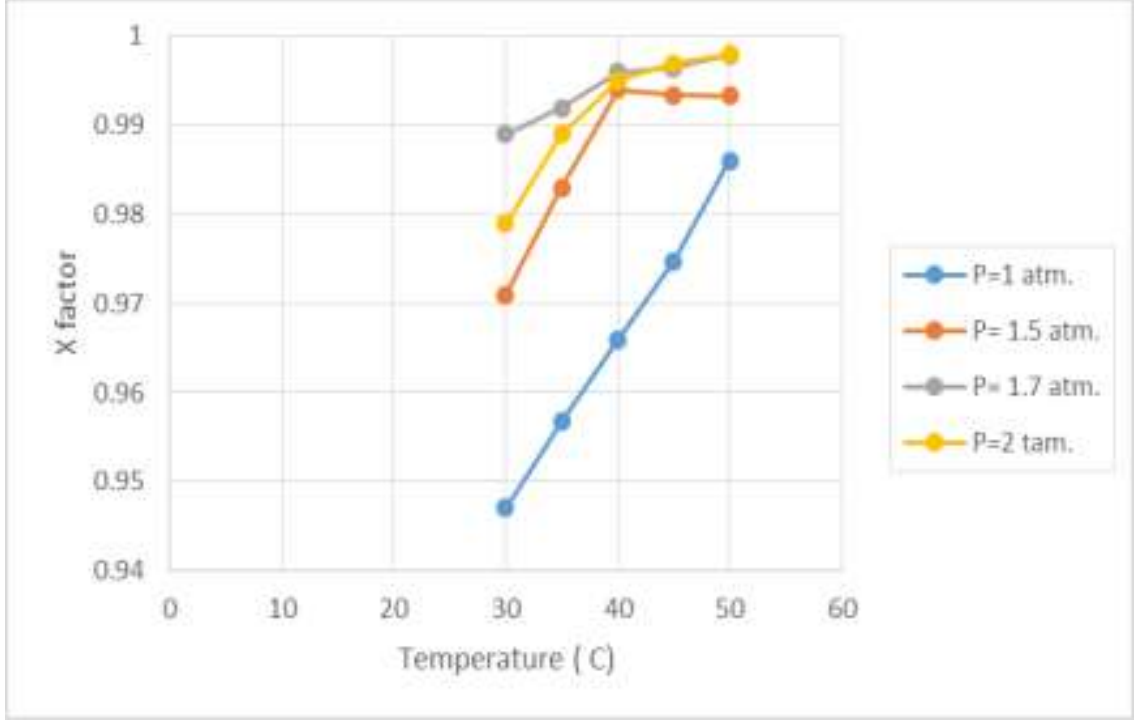

Fig. 1: Values of $\mathrm{X}$ factor versus operation conditions.

The increase in temperature decreases the value of sulfure in the outlet stream so increases the value of $\mathrm{X}$ factor at all amounts of pressures. The trend of changes in amounts of $X$ factor is different for $1 \mathrm{~atm}$ from the other values of pressure. It seems that at $1 \mathrm{~atm}$, the best temperature which helps the adsorption process is $50 \mathrm{C}$ with value of 0.986 for $\mathrm{X}$ factor. However, the incraese trend of $\mathrm{X}$ factor from $30 \mathrm{C}$ to $40 \mathrm{C}$ of operation tempertaure changes to decrease trend with slight slop from $40 \mathrm{C}$ to $50 \mathrm{C}$ at pressure of $1.5 \mathrm{~atm}$. So, the best values of temperature for $1.5 \mathrm{~atm}, 1.7 \mathrm{~atm}$ and 2 atm are 40 $\mathrm{C}, 50 \mathrm{C}$ and $50 \mathrm{C}$, respectively. The realted values of $\mathrm{X}$ factor are 0.9940, 0.9979 and 0.998, respectively. Also, the values of $\mathrm{X}$ factor at 30, 35 and $40 \mathrm{C}$ and 1.7 atm are higher than those are obtained at 2 atm and the same temperatures. This shows that $1.7 \mathrm{~atm}$ is the appropraite pressure for the related adsorption process. Although at this pressure $(1.7 \mathrm{~atm})$, the temperature enhancement augments the sulfure adsorption but evaporation loss may occur at the higher temperature. On the other hand, more energy requirements are needed to reach higher operation temperature. So, $35 \mathrm{C}$ is considered as the proper temperature.

\section{Investigation of mass transfer driving force}

Sulfur initial concentration in the oil stream affects the amount of outlet sulfur from the bed. So, experiments are held in a catalytic bed contains $50 \mathrm{~nm}$ in diameter nano catalyst with $5 \mathrm{~cm}$ height and $2 \mathrm{~cm}$ bed diameter. Initial sulfur concentration in feed oil varies in value of $30,45,50$, 55 and $65 \mathrm{ppm}$. At each experimental run, the used catalytic bed is replaced by a fresh catalytic bed. Figure 2 shows the changes in the amount of $\mathrm{X}$ factor versus the initial sulfur content. Although the increase in the amount of initial concentration increases the initial concentration driving force between oil and nano catalyst, the bed adsorption capacity is limited and the sulfur removal is disturbed at high initial sulfur in the inlet oil. So, the increase in the amount of inlet sulfur decreases the amount of $\mathrm{X}$ factor. However, totally the all amounts of $\mathrm{X}$ factor are higher than 0.97 in all experiments. The changes in the amount of initial concentration from $30 \mathrm{ppm}$ to $50 \mathrm{ppm}$ and from $30 \mathrm{ppm}$ to 65 ppm decrease the amount of $\mathrm{X}$ factor just $0.07 \%$ and about $1.7 \%$, respectively. The sudden decrease in the amount of $\mathrm{X}$ factor after 50 ppm shows the determined adsorption capacity for the used catalytic bed. 


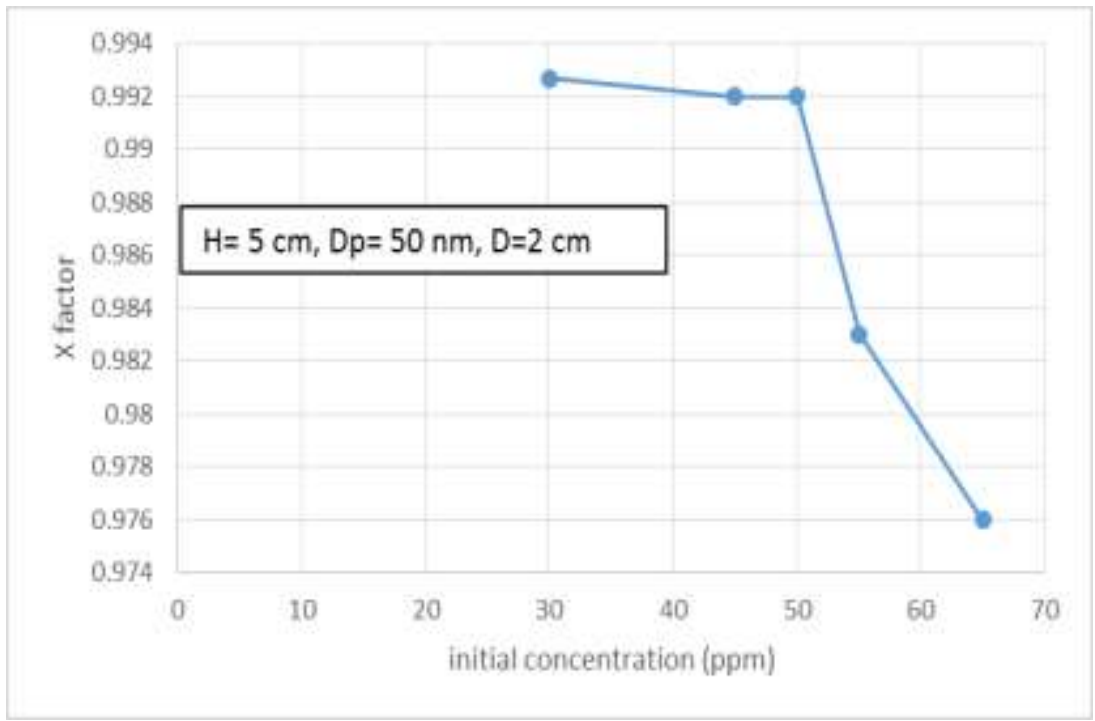

Fig. 2: $\mathrm{X}$ factor versus the initial concentration.

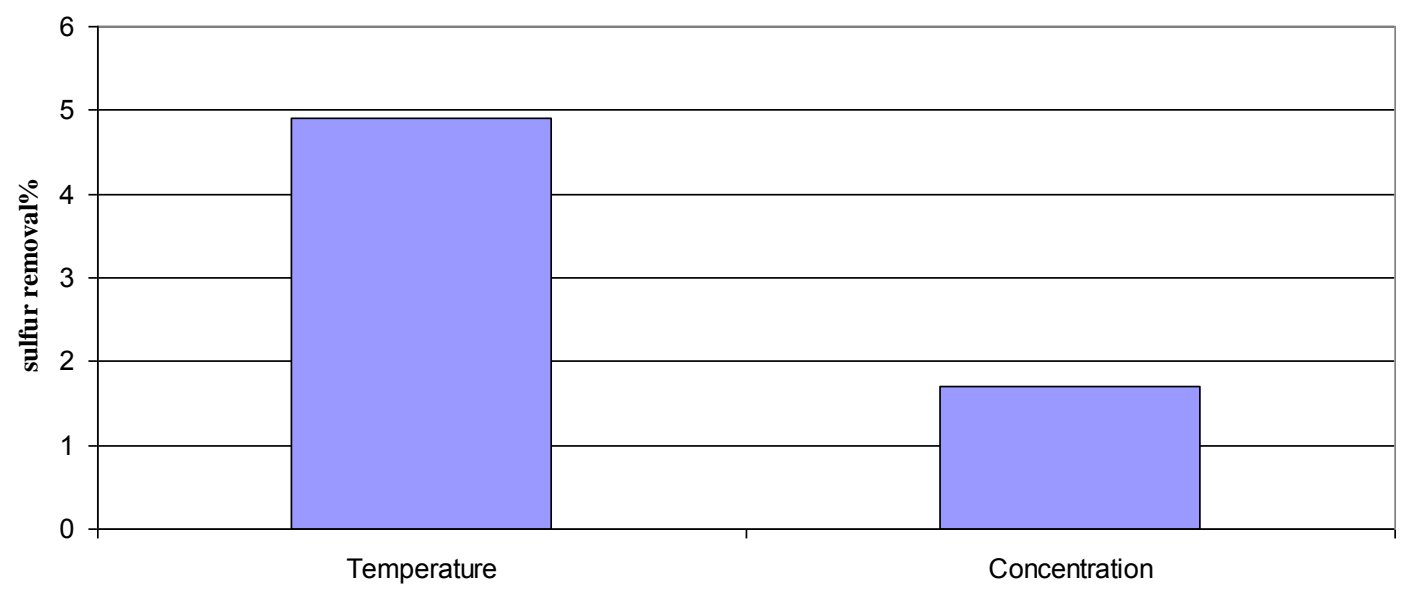

The effect of operating temperature and initial concentration

Fig. 3: The effect of operating temperature and initial concentration on the quality of sweetening process.

The effect of operating temperature as operating condition and also, the initial concentration on the desulfurization process is evaluated in the Figure 3. The effect of operating temperature and intial concentration on the sweetening process is $4.9 \%$ and $1.71 \%$, respectively.

\section{CONCLUSION}

Nano catalytic reactor includes mixed metallic oxide characteristics are evaluated in oil sweetening process experimentally, in this study. Optimum operation temperature and pressure, bed length and bed diameter, oil flow rate, catalyst diameter and sulfur initial concentration are analyzed by value of $\mathrm{X}$ factor and selected. The higher value of conversion factor, $\mathrm{X}$ factor, considering the cost is the purpose of the experiments.

Low temperature range $30,35,40,45$ and $50 \mathrm{C}$ at low pressure range of 1, 1.5, 1.7 and $2 \mathrm{~atm}$ are applied and $35 \mathrm{C}$ and $1.7 \mathrm{~atm}$ is proposed as the best value of operation conditions. Although the higher temperature leads the higher value of $\mathrm{X}$ factor but evaporation loss and also energy requirement limits the operation conditions. $X$ factor of 0.992 is obtained at this condition.

\section{REFERENCES}

[1] Yuxiao Niu, Mingyang Xing, Baozhu Tian, Jinlong Zhang, 2012, "Improving the visible light photocatalytic activity of nano-sized titanium dioxide via the synergistic effects between sulfur doping and sulfation, "Applied Catalysis B: Environmen., 115-116 (5) pp. 253-260.

[2] Rao Mumin, Song Xiangyun, Cairns Elton J., 2012, 'Nano-carbon/sulfur composite cathode materials with carbon nanofiber as electrical conductor for advanced secondary lithium/sulfur cells," J. Power Source., 205 (1), pp. 474-478. http://dx.doi.org/10.1016/j.jpowsour.2012.01.047

[3] Zhang Yongguang, Zhao Yan, Konarov Aishuak, Gosselink Denise, Soboleski Hayden Greentree, Chen P., 2013, "A novel nanosulfur/polypyrrole/graphene nanocomposite cathode with a dual-layered structure for lithium rechargeable batteries,'” J. Power Source., 241 (1), pp. 517-521.

http://dx.doi.org/10.1016/j.jpowsour.2013.05.005

[4] Hosseinkhani M., Montazer M., Eskandarnejad S., Rahimi M.K., 2012, "Simultaneous in situ synthesis of nano silver and wool fiber fineness enhancement using sulphur based reducing agents, "Colloids and Surfaces A: Physicochem. Eng. Aspect., 415 (5), pp. 431-438. http://dx.doi.org/10.1016/j.colsurfa.2012.09.009 
[5] Christoforidis Konstantinos C., Figueroa Santiago J.A., Fernández-García Marcos, 2012, ''Iron-sulfur codoped $\mathrm{TiO}_{2}$ anatase nano-materials: UV and sunlight activity for toluene degradation, "Applied Catalysis B: Environment., 117-118 (18), pp. 310-316.

http://dx.doi.org/10.1016/i.apcatb.2012.01.029

[6] M. de las Obras-Loscertales, A. Rufas, L.F. de Diego, F. García-Labiano, P. Gayán, A. Abad, J. Adánez, Effects of Temperature and Flue Gas Recycle on the $\mathrm{SO}_{2}$ and $\mathrm{NO}_{\mathrm{x}}$ Emissions in an Oxy-fuel Fluidized Bed Combustor, Energy Procedia., 2013; 37: 1275-1282. http://dx.doi.org/10.1016/j.egypro.2013.06.002

[7] W. Kaewboonsong, V.I. Kuprianov, N. Chovichien, Minimizing fuel and environmental costs for a variable-load power plant (co-)firing fuel oil and natural gas: Part 1. Modeling of gaseous emissions from boiler units, Fuel Processing Technology, 2006; 87: 1085-1094 http://dx.doi.org/10.1016/j.fuproc.2006.08.003

[8] A.Irabien, Environmental and economic evaluation of $\mathrm{SO}_{2}$ recovery in a ceramic hollow fibre membrane contactor. Chem Eng Process: Process Inten., 2012; 52: 151-154.

http://dx.doi.org/10.1016/j.cep.2011.10.006

[9] H. Wang, Sh. Li, F. Lai, B. Wang, Computational Model of Greenhouse Gas Emissions of Power Station boiler Considering Desulphurization, Physics Procedia, 2012; 24: 44-49. http://dx.doi.org/10.1016/i.phpro.2012.02.008

[10] D.L. Stern, K.E. Nariman, J.S Buchanan, N.A. Bhore, D.L. Johnson, R.K. Grasselli, The Mobil Oil SO Treatment Process (MOST). Catalytic removal of $\mathrm{SO}_{\mathrm{x}}$ and $\mathrm{H}_{2} \mathrm{~S}$ from refinery tail gas, Catalysis Today, 2000; 55 : 311-316.

http://dx.doi.org/10.1016/S0920-5861(99)00240-0 